\title{
Editorial: Down into Egypt
}

The Oxford Companion to English Literature calls it 'a didactic romance'. Everyman's Library includes it in one of its volumes of 'shorter novels' of the eighteenth century. Works of similar length by Henry James and D. H. Lawrence are usually classified as tales. Its author, Dr Samuel Johnson, entitled it The History of Rasselas, Prince of Abyssinia. It might equally fairly be described as a Platonic dialogue, a meditation for numerous voices on 'moral subjects': life and man, knowledge and ignorance, the passions and the sentiments, poetry and art, marriage and children, and above all the Socratic question of 'the choice of life'. Disagreement or uncertainty about what term to use in the summary description of a thing is often expressed by saying that we don't know what the thing is or is like: 'That was a way of putting it-not very satisfactory'. But many a successful characterization consists in offering one by one, and one by one withdrawing, a set of terms that are individually near misses but jointly amount to a subtle and expressive portrait of what we are trying to represent.

The principal voices are the eponymous hero and his sister the Princess Nekayah, the Prince's scholarly and philosophical mentor Imlac and the Princess's Lady in Waiting Pekuah. These four, with their attendants, escape from the stiflingly paradisal Happy Valley of their native Abyssinia and explore Egypt in search of the key to life. Though Pekuah is kidnapped and ransomed, little else in the way of an external event is allowed to interrupt the intellectual action. It gradually becomes clear that the supposed secret of life is chimerical, and that wisdom consists in grasping and responding to facts and circumstances largely beyond our control. The dialogue duly ends in Socratic aporia. The last chapter is entitled 'The Conclusion, in which Nothing is Concluded'. It records the ambitions retained or developed by the chief characters during their journeyings:

Pekuah was never so much charmed with any place as the convent of St Anthony, where the Arab restored her to the princess, and wished only to fill it with pious maidens, and to be made prioress of the order; she was weary of expectation and disgust, and would gladly be fixed in some invariable state.

The princess thought, that of all sublunary things knowledge was the best: she desired first to learn all sciences, and then proposed to found a college of learned women, in which she would preside, that, by conversing with the old, and educating the young, she might divide her time between the acquisition and communication of 


\section{Editorial}

wisdom, and raise up for the next age models of prudence, and patterns of piety.

The prince desired a little kingdom, in which he might administer justice in his own person, and see all the parts of government with his own eyes; but he could never fix the limits of his dominion, and was always adding to the number of his subjects.

Imlac and the astronomer were contented to be driven along the stream of life, without directing their course to any particular port.

Of these wishes that they had formed they well knew that none could be obtained. They deliberated awhile what was to be done, and resolved, when the inundation should cease, to return to Abyssinia.

But the work as a whole is a mosaic of details, and only by seeing its details can it be understood and assessed. There is the reclusive astronomer, whose reason is so threatened by his isolation and his concentration on the skies that he comes to suppose that he has power over the climate and the seasons, and hence over the whole human world; the hermit who has all along had a treasure hidden in his cave, ready to support him on his return to a more comfortable world; the rigidly Stoic moralist whose vaunted apatheia cracks and melts at the death of his daughter: 'What comfort can truth and reason afford me? Of what effect are they now, but to tell me that my daughter will not be restored?'

The history of Rasselas preaches as well as practises the use of a dialectical method, and illustrates its value in our communion with ourselves as well as in our conversation with others. The Princess puts it well:

To the mind, as to the eye, it is difficult to compare with exactness objects vast in their extent, and various in their parts . . . We differ from ourselves, just as we differ from each other, when we see only part of the question, as in the multifarious relations of politics and morality; but when we perceive the whole at once, as in numerical computations, all agree in one judgment, and none ever varies his opinion.

Rasselas at one point tells Imlac that he intends 'to devote himself to science, and pass the rest of his days in literary solitude'. It is clear that 'science' and 'literature' are both used in wider senses than is now customary, so widely that there is a substantial overlap between their territories. In a philosophical conversation a scholar declares his opinion 'that instead of the tardy conveyance of ships and chariots, man might use the swifter migration of wings; that the fields of air are open to knowledge, and that only ignorance and idleness need crawl upon the ground'. The prince rejoins with a conclusive difficulty: even swim- 
ming in water is laborious; the operation of wings will be too strenuous for human strength.

Rich though Rasselas is in Johnsonian sobriety and common sense, it contains at least one phrase that was capable of influencing Shelley: the poet is described as 'the interpreter of nature, and the legislator of mankind'. 